\title{
Reconception of Information Commission Arrangements as a Response to the Digitalization Development of Public Information in Indonesia
}

Kadek Cahya Susila Wibawa ${ }^{1}$, Irma Cahyaningtyas ${ }^{2}$, Adya Paramita Prabandari ${ }^{3}$ \{kadekwibawa@lecturer.undip.ac.id ${ }^{1}$, irmafjr83@gmail.com², apprabandari@gmail.com ${ }^{3}$ \}

Universitas Diponegoro, Indonesia ${ }^{1,2,3}$

\begin{abstract}
This paper aims to analyze the existing conditions of the Information Commission (KI) from the perspective of the institution and authority, which will lead to a reconception regarding the arrangement of the Information Commission as a response to the development of digitalization of public information in Indonesia. Digitalization of information is changing information from analog to digital format and the development of the digitalization of information has positively and negatively impacted Indonesia. As a state auxiliary organ in charge of public information, the Information Commission needs to conduct a self-evaluation that will produce a progressive and responsive Information Commission. The results of this study indicate that the Information Commission is institutionally not independent, and in terms of authority, there is an overlapping authority in resolving public information disputes with the administrative court. There is a dualism in the process of resolving public information disputes. A reconception is also needed regarding selecting and recruiting candidates for the Information Commission Commissioner. It is time for the Information Commission to be filled with young people with excellent capabilities. The Information Commission also needs to be filled with a progressive and responsive commissioner.
\end{abstract}

Keywords: Information Commission, Digitization of Information, Public Information

\section{Introduction}

One of the main principles of implementing good governance in governance is the principle of transparency and openness of public information [1]. It is complicated for the government not to meet the demands of information disclosure from the public in an atmosphere of advancing technology and information [2]. It is done based on the premise that the government which runs the government openly has democratic values and the principles of good governance. Cangara [3] further stated that: "The government must be able to reform itself and read the signs of the times about the growing demands of society for transparency on policies that concern the interests of many people". Therefore, it is right for the public to know public information. The right to information is a derogable right (one of the human rights) [4]. Golwal and Kalbande [5] stated that "right to know is also closely linked with other basic rights such as the right to good health facilities, right to education, right to freedom of speech and expression, right to a decent job, etc.". There are all attributes of freedom.

The advancement of information technology has provided a comprehensive source of information and communication from what humans already have [6]. The advances in 
information technology are the beginning of the development of e-government, which has promoted increased digital connectivity in organizational, private, and public life [7].

The development of digitalization of information has forced the Indonesian nation to enter the industrial era 4.0, marked by interconnectivity, a combination of intelligent system development and automation (unifying the real world and the virtual world). As institutions that manage public information, government institutions must respond to developments in the digitalization of information. The digitalization of public information in its development will also cause various problems: legal, social, cultural, ethical, and so on.

Requests for digital public information will often lead to disputes between the applicant, and the public information manager results of the conflict are not predetermined [8]. Kurniati [8] stated that: "A conflict changes or develops into a dispute when the aggrieved party has expressed dissatisfaction or concern, either directly to the party that is considered to be the cause of the loss or to another party".

Based on point 5 Article 1 of the Act Number 14 of 2008 concerning the Public Information Openness Act/PIO Act, it states that public information disputes are disputes between users of public information and public bodies relating to the right to obtain and use information based on legislation. Disputes of public information may occur due to: a) refusal of requests for public information; b) periodic information is not provided; c) requests for information are not responded to by officials or public bodies; d) requests for information are not responded adequately to; e) requests for public information are not fulfilled; f) imposition of an unreasonable fee; g) and/or delivery of information that exceeds the time set in the act (vide Article 35 PIO Act).

Paragraph (1) letter (a) Article 26 of PIO Act regulates the main tasks of the Indonesian Public Information Commission (KI), namely: 1) receiving, examining, and deciding requests for resolution of Public Information Disputes through Mediation and/or non-litigation Adjudication submitted by every Public Information Applicant based on the reasons referred to in the Public Information Openness Act; 2) establish general policies for public information services; and 3) stipulating implementation instructions and technical instructions. The $\mathrm{KI}$ is assigned by law as a public information dispute resolution institution in Indonesia.

Based on reports of the Information Commission (2010-2019), the KI notes that it has received 2928 requests for the resolution of public information disputes [9]. There were 682 requests of public information dispute (2018) that had not been solved KI. In 2019, the number of unsolved cases increased by 63 cases. So that the total number of unsolved cases in 2019 are 745 cases [9].

Empirically, public information dispute resolution through the KI has not been effective. The respondent refuses to attend or sends representatives to participate in the hearing at the KI even though the commissioner wants to speak directly with the decision-maker of a public body [10]. The Information Commission should have the authority to execute in resolving public information disputes so that its decisions will be far more effective and obeyed by the parties. Another problem in the Information Commission institution is related to the institution's independence as the front guard in overseeing the openness of public information and the resolution of public information disputes and the weak position and nature of the relationship between the Information Commission. It can be seen from the role of the Regional Information Commission (KPID), which is still under the regional government offices or agencies.

The growing digitization of information demands that the Information Commission be more responsive and progressive in dealing with public information disputes. It is necessary to reconceptualize the Information Commission institution to optimize the duties, roles, and powers of the Information Commission and strengthen the institution's position. This paper will outline 
the reconception of the Information Commission's arrangements as a response to the development of the digitalization of public information in Indonesia.

\section{Research Method}

This research uses two types of legal research: doctrinal legal research supported by nondoctrinal legal research. The combination of the two studies is to get a more comprehensive result. Doctrinal legal research uses a statutory approach and a conceptual approach. Doctrinal (normative) law research is carried out by searching and analyzing legal materials, primary legal materials, and secondary legal materials. In the statutory approach, an analysis is carried out on UUD NRI 1945, PIO Act, and Information Commission Regulation (PerKI) Number 1 of 2013. This research relies on the constructivism paradigm related to non-doctrinal legal research [9]. A constructivist philosophical paradigm is an efficient tool that can yield many benefits when implemented in the carrying out of research in a diverse field of study and in undertaking teaching and learning activities at any educational level [11].

This research uses a constructive qualitative approach in analyzing research results. Qualitative research is research used to describe, explain, investigate, and then discover the quality or social influence's features that cannot be measured, defined by a quantitative approach [12]. Constructive in this research means that the analysis is not only a description but also at the interpretive stage and ultimately reconstructs related to the settlement of public information disputes in Indonesia [9].

\section{Results and Discussion}

\subsection{Existing Conditions Weak Position and Authority of the KI in Indonesia}

Public information disclosure in Indonesia has not been effective and efficient. One of the reasons for this was the weak position and authority of the KI in Indonesia. The Indonesia KI is a mandate of the PIO Act where the functions, duties, and powers are specified in law enforcement in the field of public information disclosure [13]. As a state auxiliary organ, the Information Commission includes a mixed domain of an executive function, quasi-judicial function, and quasi-legislative function [13].

Paragraph (1) Article 24 of the PIO Act states that the KI consists of the Central Information Commission (KIP), the Provincial Information Commission (KID-Province), and if needed, the Regency/City Information Commission (KID-Regency/City). The PIO Act does not regulate the nature of the institutional relationship between the KI and the KID Province/Regency/City [2]. Furthermore, Article 26 paragraph (2) letter b and paragraph (3) of the PIO Act also has weaknesses related to the non-regulation of duties and authority to disseminate information on the implementation of public information disclosure both at the central and regional levels [2]. It has also contributed to the weak position and authority of the KI in Indonesia.

The weak position and nature of the relationship of the KI can be seen from the role of the KID that is still under the service or regional government agencies. Even though Article 23 of the PIO Act states: The KI is an independent institution whose function is to implement this act and its implementing regulations establish technical guidelines for public information service 
standards and resolve public information disputes by mediation and/or non-litigation adjudication [9].

The overlapping of authority within the KI is also seen like the working relationship between the KIP and the KI in provinces and districts/cities, which is not hierarchical, so empirically what happens is that the KIP also carries out activities to receive, examine and decide disputes information that occurs in the province and district/city.

There is a dualism of information dispute settlement routes regarding information dispute resolution. In Indonesia, the settlement of public information disputes can be solved in two ways, namely: the KI and State Administrative Court (PTUN); it is based on the Act Number 30 the Year 2014 concerning Government Administration (GA Act) and the PIO Act [9]. Wibawa \& Putrijanti [9] further stated that no explicit regulation in the IPO Act causes the dualism of settlement of public information disputes. The objections and dispute resolution in Public Information Openness are prerequisites for filing legal remedies through PTUN (in adjudicating public information disputes involving state public bodies). This inconsistency is a natural thing considering that the GA Act was passed after the PIO Act. Thus, the legislators of the Public Information Openness Act may not take into account that real actions of state public bodies can be subjected to claims in PTUN (vide Article 1 Number 18 of the GA Act).

\subsection{New Concept of Regulating the Position and Authority of the KI in Indonesia}

In the socio-political study, the definition of an institution covers a broad aspect [14]. The breadth of this coverage can be seen from the description suggested by Scott [15] that institutions are social structures with a high level of resilience, consisting of cultural-cognitive, normative, and regulatory elements related to resources, providing stability and meaning in social life. The regulatory pillar emphasizes the rules and arrangements for sanctions, including regulations, legal norms, and operational procedures. The normative pillar contains evaluative dimensions and obligations, such as professional standards and responsibility. Meanwhile, the cultural-cognitive pillar involves shared conceptions and frames that understand the meaning. Each of these pillars provides different reasons for legitimacy, both based on punitive sanctions, moral and cultural authority in the arena of individual and group identity construction [15].

Concerning the Information Commission institution in Indonesia, a new concept is needed to regulate the position and authority of the KI by strengthening the Information Commission institution. The first thing that can be done is the independence of the Information Commission, both at the central and regional levels, which must be made to strengthen the implementation of public information disclosure. A fundamental change needs to be made, namely by changing the pattern of relations between the KIP and KID, which should be hierarchical [2]. Ideally, the parties to the conflict (in the context of public information disputes) must first seek a solution through administrative-legal measures (objections and administrative appeals) [9]. Hermanto \& Sudiarawan [16] stated that the Complaints can be submitted to the agency that issued the decision or to a higher institution vertically. The synchronization of PIO Act and Related Laws and Regulations, such as; PTUN Act, GA Act, Judicial Power Act, and the Supreme Court Act. This condition must be solved as fast as possible [9]. 


\subsection{Increasing the Capability of Information Commission Commissioners that is Progressive and Responsive to the Digitalization Development of Public Information in Indonesia}

The development of digitizing information cannot be separated from the development of information technology. The urgency of the role of technology in the process of accelerating information occurs when the results of technology can help change communication patterns and structures that are limited by time and space into an unlimited pattern of information communication [17]. Technology and digital media can spur the creation of new networks and acceleration. The growth rate and development of information are exponential [17]. It means that information received by the public or by everyone can constitute a flood of information.

The digitization of information can have both positive and negative impacts in all areas of people's lives. The positive effects of the development of digitalization of information include: a) Easy and fast access to information; b) developing innovations based and oriented towards digital technology; c) The development of digital-based mass media; d) The development of applications in various sectors, such as: in the education sector, the emergence of online libraries, online learning, the emergence of e-marketplaces, e-commerce, etc. Meanwhile, the negative impacts of the development of digitalization of information include: a) The number of violations of Intellectual Property Rights (IPR) is increasing, this is due to the ease of data access that makes it easier to plagiarize a work; b) The development of cyber-crime; etc.

Seeing the challenges in the development of digitalization of information, in addition to institutional strengthening, there should also be efforts to increase the capability of the Information Commission to respond to these challenges. Capability is the ability to carry out tasks and functions, consisting of 3 (three) interrelated elements: the authority, capacity, and competence of Human Resources (HR) that the apparatus must have to carry out its role effectively [18]. Furthermore, Eldyani \& Wardoyo [19] stated that: "the success of an institution or organization in achieving its objectives, one of which is influenced by the human resources possessed by the institution or organization. Therefore, these institutions or organizations need talented human resources.

Capability and competency development are related to increasing the knowledge of intellectual or emotional abilities needed to do a better job. Human resource development rests on the fact that the apparatus requires ever-developing knowledge, expertise, and abilities [20]. This increase can be obtained in several ways, such as: through education, training, seminars, etc.

Based on this, the Commissioner of the Information Commission, both at the central and regional levels, is obliged to improve their capabilities and competencies through various short training, attending seminars, webinars, focus group discussions, and education. The ability of the Information Commission Commissioner must continually be updated and upgraded to follow the development of information in the digital era. Regarding the progress and responsiveness of Information Commission Commissioners, it can be pursued by reorganizing the selection and recruitment system for Information Commission Commissioners. The recruitment system for the Commissioner of Information can also be rearranged by, for example, accepting candidates for commissioners who are young but have high performance and have taken a minimum master's education. Regulations related to youth are needed because the digital era belongs to millennials. The current development will be complicated to follow for Commissioner candidates who still have an analog paradigm. The commissioners now required are commissioners who are progressive and responsive. It is necessary to accommodate Commissioner candidates who have progressive thoughts and are responsive to the changes and 
developments of the times, especially the development of digitalization of information that is currently sweeping the entire world, including Indonesia.

\section{Conclusion}

The conclusions that can be drawn are: that the current condition of the Information Commission, it turns out that the position of the Information Commission is still weak. Its institutional authority is still not maximal, and there is an overlap with administrative court authority related to the resolution of public information disputes. The new concept is related to the position of the KI, the most important of which is to place the KI as an independent institution, which is given flexibility in financial management, institutional arrangements, and changes in accountability.

Reconception of the Information Commission's arrangements can also be made by increasing the capability of the Information Commission Commissioner. The Information Commission needs commissioners capable, progressive, and responsive to changes in public information in the digital era.

\section{Acknowledgments}

We gratefully acknowledge that our participation in this conference was financially supported by The Faculty of Law, Universitas Diponegoro.

\section{References}

[1] R. Rasyid, Desentralisasi dalam menunjang pembangunan daerah dalam pembangunan administrasi di Indonesia. Jakarta: Pustaka LP3ES, 1998.

[2] A. Budiman, Penguatan keterbukaan informasi publik. Jakarta: Pusat Penelitian Badan Keahlian DPR RI, 2017.

[3] H. Cangara, Komunikasi Politik; Teori, Konsep, dan Strategi. Jakarta: Rajawali Pers, 2011.

[4] K. C. S. Wibawa, "Urgensi Keterbukaan Informasi dalam Pelayanan Publik sebagai Upaya Mewujudkan Tata Kelola Pemerintahan yang Baik," Adm. Law Gov. J, vol. 2, no. 2, pp. 218-234, 2019.

[5] M. D. Golwal and D. T. Kalbande, "Right to Information Information Literacy and Public Libraries," Asia Pacific J. Manag. Entrep. Res., vol. 1, no. 1, p. 89, 2012.

[6] Y. R. Sipayung and K. C. S. Wibawa, "The role of information technology toward the development of online learning process in covid-19 pandemic period in Indonesia," PalArch's $J$. Archaeol. Egypt/Egyptology, vol. 17, no. 4, pp. 948-958, 2020.

[7] R. Sijabat, "Analysis of e-Government Services: A Study of the Adoption of Electronic Tax Filing in Indonesia," J. Ilmu Sos. dan Ilmu Polit., vol. 23, no. 3, pp. 179-197, 2020.

[8] N. Kurniati, ““"Mediasi-Arbitrase” Untuk Penyelesaian Sengketa Tanah,” Sosiohumaniora, vol. 18, no. 3, pp. 197-207, 2016.

[9] K. C. S. Wibawa and A. Putrijanti, "The Reconstruction of Public Information Dispute Resolution as the Effort in Realizing Substantive Justice in Indonesia," J. Environ. Treat. Tech., vol. 9, no. 1, pp. 110-116, 2021.

[10] A. W. Fatoni, "Penyelesaian Sengketa Keterbukaan Informasi Publik Melalui Ajudikasi dalam Undang-Undang Nomor 14 Tahun 2008 tentang Keterbukaan Informasi Publik,” J. Ius Const., 
vol. 4, no. 1, pp. 78-94, 2019.

[11] D. Adom, A. Yeboah, and A. K. Ankrah, "Constructivism philosophical paradigm: Implication for research, teaching and learning," Glob. J. arts Humanit. Soc. Sci., vol. 4, no. 10, pp. 1-9, 2016.

[12] S. N. Susanto and K. C. S. Wibawa, "The Existence of The Indonesia Peatland Restoration Agency in Perspective of Organization and Authority," Adm. Law Gov. J., vol. 3, no. 1, pp. 92 $103,2020$.

[13] A. Ghafur, E. Firdaus, and I. H. Putmana, "Tinjauan Yuridis terhadap Kewenangan Komisi Informasi Berdasarkan Undang-undang Nomor 14 Tahun 2008 Tentang Keterbukaan Informasi Publik,” Riau University, 2014.

[14] A. Subhan, "Penguatan kelembagaan komisi informasi daerah dalam mendukung transparansi pemerintahan (Studi Kasus Keterbukaan Informasi Publik di Provinsi Jambi)," Kajian, vol. 21, no. 3, pp. 237-255, 2017.

[15] R. W. Scott, "Institutions and Organizations (pp. 460-484)." Thousand Oaks, CA/Oxford: Sage/Development, Oxford University Press, 2001.

[16] B. Hermanto and K. A. Sudiarawan, "Rekonstruksi Pergeseran Paradigma Upaya Administratif Dalam Penyelesaian Sengketa Pra Pemilihan Kepala Daerah,” J. Legis. Indones., vol. 16, no. 3, pp. 325-343, 2019.

[17] A. G. E. W. Wuryantai, "Digitalisasi masyarakat: Menilik kekuatan dan kelemahan dinamika era informasi digital dan masyarakat informasi," 2004.

[18] S. R. Masdan, V. Ilat, and W. Pontoh, "Analisis Kendala-kendala Peningkatan Kapabilitas Aparat Pengawasan Intern Pemerintah (APIP) pada Inspektorat Kabupaten Gorontalo," J. Ris. Akunt. DAN Audit. GOODWILL", vol. 8, no. 2, 2017.

[19] P. Eldyani and P. Wardoyo, "Upaya Peningkatan Kompetensi: Dampak Pelatihan Bersubsidi Serta Peran Instruktur,” J. Ris. Ekon. dan Bisnis, vol. 11, no. 2, pp. 142-153, 2018.

[20] Miftahuddin, A. Rahman, and A. I. Setiawan, "Strategi Manajemen Sumber Daya Manusia Dalam Meningkatkan Kinerja Karyawan,” Tadbir J. Manaj. Dakwah, vol. 3, no. 2, pp. 1-16, 2018. 